\title{
Macerals of C1 Coal Seam in Parvade Coalfield (Tabas- Iran)
}

\author{
Seyed Mohammad Hashemi \\ Department of Geology, Mashhad Branch, Islamic Azad University, Mashhad - Iran \\ E-mail:dhashemi@iaum.ac.ir
}

\begin{abstract}
This paper deals with the study of the Late Triassic coal deposits from Parvade coalfield in south of Tabas town and located geologically this is part of Central Iran zone. Coal main seam in Parvade coalfield named C1.Coals are rich in vitrinite, with average contents of $\mathbf{9 0 \%}$.Collinite is main part of vitrinite. their structures are homogenous .Telinite is low amount of vitrinite, based on ratio of collinite to telinite ,subsidence of swamp is gradually and conditions of environments is reduction and PH is acidic .Lithotype of coals is most ultraclarain with high amount of vitrinite .some of amounts presents of semi-vitrinite and fusinite , micronite, skelerutinite and semi-fusinite macerals. High content of the vitrinite group macerals in these coals shows that water level was relatively high .Amount of vitrinite played key roles in coking.
\end{abstract}

Keywords - Macerals ; Vitrinite; Ultraclarain; Parvade coalfield- Iran

\section{INTRODUCTION}

Considering their situation in the east of Iran, Parvade coalfield in Tabas has a special importance. They have been studied simply while preparing a geology map and report for Naybandan. This research is the first systematic study of their petrography and the aim is examining the petrogenesis of coals of this region.

\section{Geology Settings}

Considering their situation in the east of Iran, Parvade coalfield in Tabas has a special importance. They have been studied simply while preparing a geology map and report for Naybandan. This research is the first systematic study of their petrography and the aim is examining the petrogenesis of coals of this region.

Parvade area is one of coalfield Tabas region which located the longitude in the $75 \mathrm{Km}$ south of Tabas between the longitudes of 564630565110 East and latitudes 3259 48 to 38215 North (Fig.1).Average height region is 730 to $1050 \mathrm{~m}$ from sea level and average height of 850 meters. According to Iran geology organization, this area is considered eastern zone of Central Iran[1].in the northern part of Parvade area is located, quite plain and salt plain and located Shotori rang in east and Kamar Mahdi mountains in west and mountains of the Triassic and Jurassic sedimentary rocks in the south of Parvade. Parvade coalfield have 1200 square kilometers in extent, Parvade area divided into by faults with NE-SW strike to five regional names Parvade 1 to 4 and are East Parvade (Table 1), and although is divided into mining blocks whit the performance results of several fault structures and geology But the range is contiguous, so that outcrops of coals are continuing during the 38 kilometers West to the East and their qualitative and quantitative changes follow of certain process. Parvade area located between two major faults of Iran, Nayband fault in the east and Kalmard fault in the west. Performance of Nayband fault caused several faults with the strike EastWest which fault Rostam is most of them in northern border Parvade area[2]. Faults have strike the North east - South west. In addition to the terms and conditions sedimentation basin features, some geological features and some quality and technological characteristics of coal seams was similar in total area and its changes is relatively certain with the rule of law and the process.

\section{C1 COAL SEAM}

Seam $\mathrm{C} 1$ be the most important seam work area Parvade I considered and includes 50 percent of total deposits balance. C1 seam located 508 meters below average Badamo and its distance is fluctuating from the lower seam, namely B2 between 20 and 50 meters. long of outcrop is $10 \mathrm{Km}$ which about 96 percent of its thick have to be to work.

According to information obtained from the boreholes been approved in almost all the $\mathrm{C} 1$ seam is available with thickness of these parts work. Seam $\mathrm{C} 1$ have fluctuations less In the southern edge and then the northern edge is identical with constant position.

The degree of seam thickness mainly medium is placed in the group. Coal seam $\mathrm{C} 1$ has in the most uniform between the coal seams Parvade. Vein thickness of $\mathrm{C} 1$ is reduced 
west to the East side, but there is appropriate thickness extracted in the Parvade.

Regenerative environment increase the amount of pyrite and Siderite Syngenetic. The swamp floor is Gradual subsidence. Based on studies for each seam of coal is started peat swamp formation from the western part of the basin and gradually expand to the East. Therefore thick coal seams decreased from West to East, and some of them are completely disappeared [3]. The number and amount of impurities, coal seams increase in the West than the East region and therefore increase amount of ash seams in the same direction.

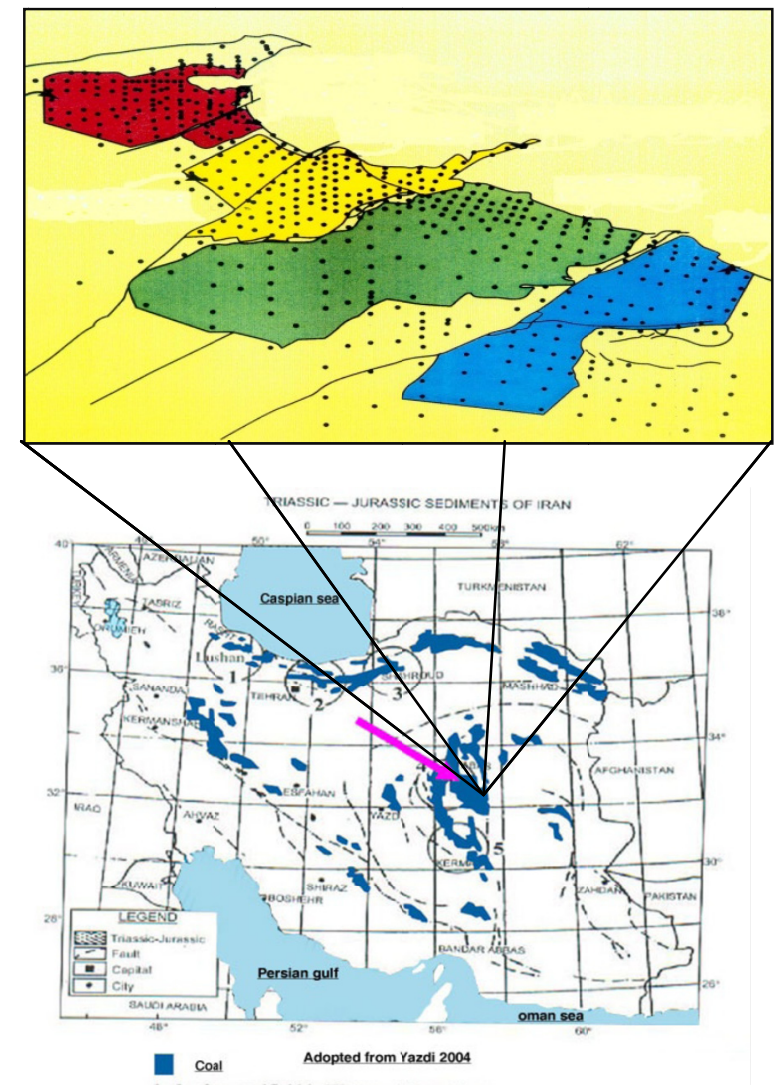

Fig. 1: Triassic- Jurassic sediments of Iran, Parvade coalfield indicated Parvade I ,II........red-Parvade III.......yellow -Parvade IV ......green Parvade V...blue

\section{IV.COALS MACERALS}

Coals are rich in vitrinite; with average contents of $90 \%$.Collinite is main part of vitrinite. Their structures are homogenous .Telinite is low amount of vitrinite, based on ratio of collinite to telinite, subsidence of swamp is gradually. This recent work has confirmed the initial supposition that the coals within the Parvade subgroup contain sufficient quantities of gas to be economically viable as a coal seam gas source. Coal volumes, depth and structure have also been confirmed from the initial work[4]. What has become apparent during this work is the variability in gas content across each of the seams in the Kerman Coal Measures and the variability in coal petrographic composition of these two units are controlled by many factors. Very low amounts of inertinite and ubiquitous bituminite lead to difficulties in interpretation of the macerals ratios [5]. Comparison with modern analogues suggests the theoretical basis for discrimination of mire type by macerals ratios is not well founded on the following grounds, absence of well structured wood tissues does not imply the absence of arbores cent vegetation; inertinite formation may be unrelated to vegetation; gelification is used in a geochemical sense and does not indicate groundwater table level (as supposed for biochemical gelification); detrital macerals often result from in situ fragmentation and not transportation[6]. Coals are rich in vitrinite, with average contents of $90 \%$. High content of the vitrinite group macerals in these coals shows that water level was relatively high .Amount of vitrinite played key roles in coking [7]. The mineral impurities coals of Parvade make up more detrital materials and clay these materials are seen as thin string or lenses scattered in Vitrinite. Other impurities in coal Parvade are carbonates calcium and iron impurities that make up small percentage of mineral and are more in joints of Vitrinite. Some of amounts presents of semi-vitrinite and fusinite, micronite, skelerutinite and semi-fusinite macerals. Telinite is low amount of vitrinite, based on ratio of collinite to telinite [8].

\section{CONCLUSIONS}

In comparison with vitrinite and exinite concentrates, inertinite macerals concentrates showed high reactivity to hydrogen at high temperatures. Coals of $\mathrm{C} 1$ seam engender of tissue lignin - cellulose of plants in inhabitant and water full of swamp. Swamp conditions been highly regenerative and $\mathrm{Ph}$ Acidic and therefore coals shiny ultraclarn formed with lots of Vitrinite. Subsidence of swamp is gradually.

\section{REFERENCES}

[1] Hashemi, S., M., Structural analysis of coal mines Parvade Tabas, undergraduate thesis Geology, Ferdowsi University of Mashhad.1993

[2] Shariat Nia, Geological features of Parvade in Tabas coal basin, Central Iran. Journal of Earth Sciences, vol.15-16, pp.50-60,1995

[3] Mukherjee, S., Mahiuddin, S., and Borthakur, P. C.,Demineralization and Desulfurization of Subbituminous Coal with Hydrogen Peroxide, Energy \&Fuels, vol..15,pp. 1418 ,2oo1.

[4] Mariana G. Yossifova ,Mineral and inorganic chemical composition of the Pernik coal, Bulgaria, International Journal of Coal Geology, Vol.72, Issues 3-4, pp. 268-292,2007.

[5] Yazdi, M., Coal: from origin to environmental impacts, Polite techniques Jahad Daneshgahi Publishing, Tehran.Iran,2003.

[6] Wells,J.J., Wigley, F., Foster, D.J., Livingston,W.R., Gibb,W.H., Williamson, J., The nature of mineral matter in a coal and the effects on erosive and abrasive behavior, Fuel Processing Technology, Vol. 86, Issue 5, Pages 535-550,2005.

[7] Bouska,V., Geochemistry of Coal, Academia Prague,pp.128141,1981 .

[8] Hashemi, S.M., 2010 , Minerals of coal main seam in Parvade coalfield (Tabas - Iran), in proc. The first international applied geology congress, Islamic Azad University, Mashhad Branch, Iran,vol.2.pp.213-220,Aprile 2010. 

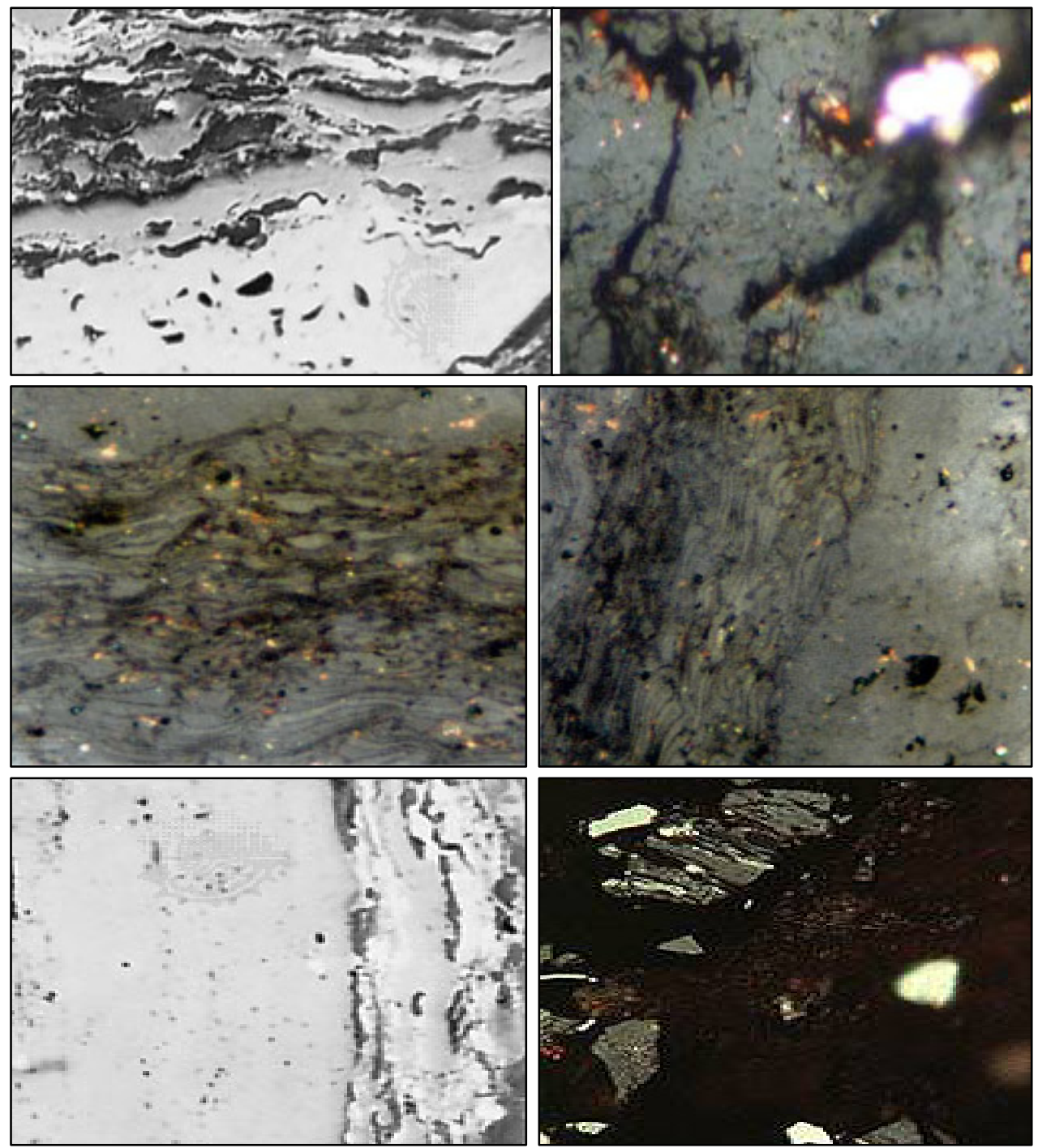

Fig3: Microscopic photos of Macerals of $\mathrm{C} 1$ seam coals vitrinite (gray) some of amounts present of semi-vitrinite and fusinite, micronite macerals, and a little Pyrite, Hematite and Clay minerals. X 40

TABLE I

CHARACTERIZES OF C1 SEAM COALS IN PARVADE MINES

\begin{tabular}{|c|c|c|c|c|c|c|c|c|c|c|}
\hline & Reserve(ht) & Tick.(m) & $\mathrm{m} \%$ & Ash \% & Vol. \% & $\mathrm{S} \%$ & $\mathrm{P} \%$ & $10 \mathrm{R}$ & $\begin{array}{c}\mathrm{X} \\
\mathrm{mm}\end{array}$ & $\begin{array}{c}\mathrm{Y} \\
\mathrm{mm}\end{array}$ \\
\hline Parvade I & 39130 & 1.83 & 0.77 & 30.39 & 21.38 & 1.32 & 0.017 & 98 & 9 & 17 \\
\hline Parvade II & 39876 & 1.52 & 0.7 & 24.07 & 24.07 & 2.82 & 0.014 & 96 & 14 & 17 \\
\hline Parvade III & 61452 & 0.92 & 0.61 & 18.36 & 24.75 & 2.27 & 0.016 & 93 & 13 & 18 \\
\hline Parvade IV & 55346 & 0.88 & 0.59 & 16.7 & 25.66 & 2.28 & 0.01 & 92 & 14 & 18 \\
\hline Parvade V & 7891 & 0.71 & 0.52 & 13.01 & 24.33 & - & - & 95 & 0 & 17 \\
\hline
\end{tabular}

